\title{
A new record of Typha shuttleworthii (Typhaceae) in Poland
}

\author{
Marcin Nobis, Agnieszka Nobis, Elżbieta Jędrzejczak \\ \& Ewelina Klichowska
}

A new record of Typha shuttleworthii (Typhaceae) in Poland. - Acta Mus. Siles. Sci. Natur., 64: 107109, 2015.

\begin{abstract}
The paper presents a new locality of Typha shuttleworthii W.D.J. Koch \& Sond. in Poland. The species was found in wet roadside ditch in Kryg village near Gorlice (ATPOL grid square EG09). The distribution map of the species in Poland is provided.
\end{abstract}

Key words: Typha shuttleworthii, distribution, Carpathians

\section{Introduction}

Typha shuttleworthii W.D.J. Koch \& Sond was recently recorded as a new to Poland (Kozłowska et al. 2012). Like the other three species representing the genus Typha, namely, T. latifolia L., T. angustifolia L., T. laxmannii Lepech, it is established in Poland (Mirek et al. 2002, Kozłowska et al. 2012).

Typha shuttleworthii is quite similar to T. latifolia and they can be easily misidentified. $T$. shuttleworthii has leaves $0.5-1.0(-1.5) \mathrm{cm}$ wide, as long as stem with inflorescence or slightly longer while leaves of $T$. latifolia are $0.8-2.0 \mathrm{~cm}$ wide and much longer than stem with inflorescence. Male inflorescence of T. shuttleworthii is 4-5(-12) cm long and significantly shorter than female inflorescence. T. latifolia has male inflorescence (5-)10-20 cm long, equal or longer than female inflorescence, sometimes slightly shorter. T. shuttleworthii and $T$. latifolia differ slightly also in length of seeds and anthers (Kozlowska et al. 2011).

In Europe, species range extends from eastern France to Ukraine and western Russia (Leonova 1979, Cook 1980, Dubina et al. 1993, Felbaba-Klushina 2011, Kapitonova et al. 2012). In Asia, it has been noted in Turkey and Iran (Baytop 1984, Hamdi et al. 2009). Typha shuttleworthii is usually recorded at lower mountain elevations. In Poland, T. shuttleworthii has been found at several localities at elevations from 500 to $600 \mathrm{~m}$ in Bieszczady and Beskid Niski Mts by Kozłowska et al. (2011). Populations of T. shuttleworthii in Poland are located on the northernmost range limit of the species in Central Europe.

Typha shuttleworthii is a semi-aquatic plant occurring both in natural and anthropogenic habitats. It grows mainly in wet ditches, stream and river valleys, in the areas of stagnant or slowly flowing waters. In Europe Typha shuttleworthii has been noticed in plant communities belonging to the Phragmitetea class or the Molinietalia order (Kozłowska et. al. 2011).

\section{New locality}

During field investigations conducted in the Beskid Niski Mts (within the Carpathian range) in 2014 new locality of Typha shuttleworthii has been found near Kryg village near Gorlice (GPS coordinates: 49 $39^{\prime} 19.8^{\prime \prime} \mathrm{N} / 21^{\circ} 16^{\prime} 31.0^{\prime \prime} \mathrm{E}$; EG09 ATPOL square $10 \mathrm{~km}$ x $10 \mathrm{~km}$; Figs 1, 2). The collected specimens of Typha shuttleworthii are deposited in the Herbarium of Jagiellonian University in Kraków (KRA).

The population of Typha shuttleworthii consisted of about 30 specimens growing in roadside ditch about 500 meters SEE from Kryg village. Specimens of the taxon occurred there together with: Juncus inflexus, Alnus glutinosa, Juncus articulatus, Lythrum salicaria, Valeriana officnalis, Alisma plantago-aquatica, Melilotus officinalis, Carex contigua, and Calamagrostis epigeios. 


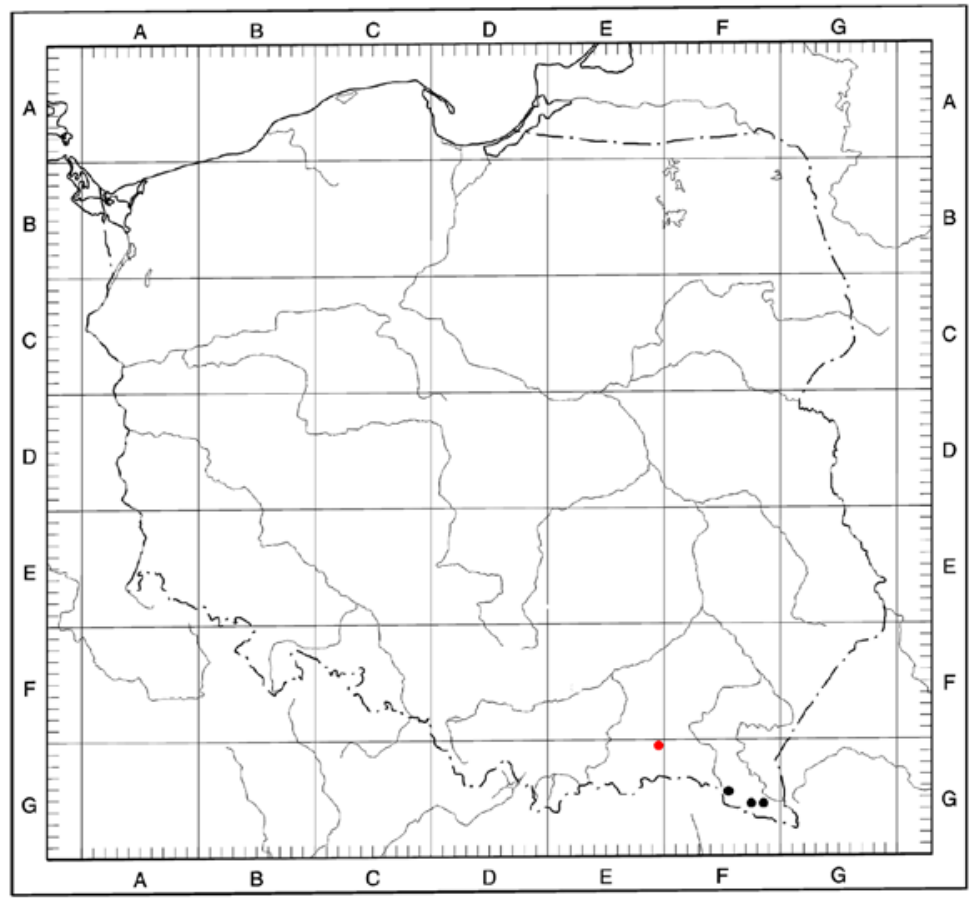

Fig 1: Distribution of Typha shuttleworthii in Poland; $\bullet-$ previously known locality, $\bullet-$ new record.

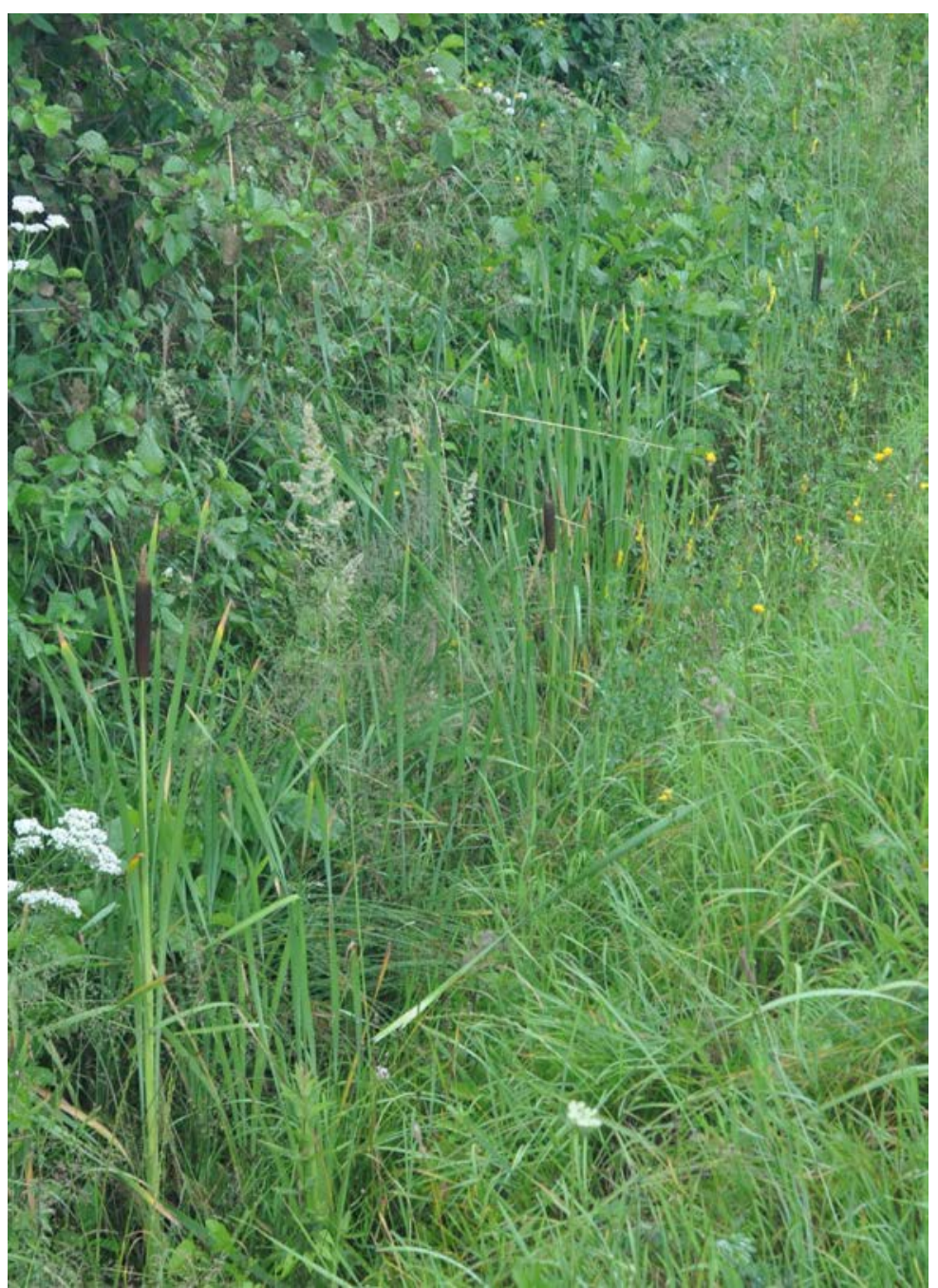

Fig 2: Typha shuttleworthii near the Kryg willage. 


\section{References}

Baytop A. (1984): Typha L. In: Davies P.H. (ed.): Flora of Turkey and the East Aegean Islands. 8: 558-563. Edinburgh University Press, Edinburgh.

Cook C.D.J. (1980): Typha L. In: Tutin T.G., Heywood V.H., Burges N.A., Moore D.M., Valentine D.H., Walters S.M. \& Webb D.A. (eds): Flora Europaea. 5: 275-276. Cambridge University Press, Cambridge, London, New York, New Rochelle, Melbourne, Sydney.

Dubina D. V., Hejny S. \& Proudova Z. (1993): Makrofiti - indikatori izmenenii prirodni sredi. Akademiya Nauk Ukraini, Institut Botaniki N. Cholodnovo, Kiev.

Felbaba-Klushyna L. (2011): Typha shuttleworthii in Ukraine and adjoining regions: tendencies of dynamics of distribution, ecological and coenotic peculiarities. - Botanica Serbica 35(2): 121-124.

Hamdi S.M.M., Assadi M. \& Ebadi M. (2009): Revision of study of Typha genus: three new records species of the genus Typha (Typhaceae) in Iran and their micromorphological pollen and capsule studies. - Asian Journal of Plant Sciences 8(7): 455-464.

Kapitonova O.A., Platunova G.R. \& Kapitonov V.I. Pogozy Vyatsko-Kamskogo kraya. Udmyrtskii univ., Izhevsk [in Russian].

Kozłowska K., Nobis A. \& Nobis M. (2011): Typha shuttleworthii (Typhaceae), new for Poland. - Polish Botanical Journal 56(2): 299-305.

Leonova T.G. (1979): Typhaceae Juss. - rogozovye. In: Fedorov A.A. (ed.): Flora evropeyskoy chastii SSSR. 2: 326-330. Izdatel'stvo Nauka, Leningrad.

Mirek Z., Piękoś-Mirkowa H., Zając A. \& Zając M. (2002): Flowering plants and pteridophytes of Poland - a checklist. W. Szafer Institute of Botany, Polish Academy of Sciences, Krakow.

Nobis M., Nobis A. \& Nowak A. (2006): Typhetum laxmannii (Ubrizsy 1961) Nedelcu 1968 - the new plant association in Poland. - Acta Soc. Bot. Poloniae 77(4): 325-332.

Zając A. (1978): Atlas of distribution of vascular plants in Poland (ATPOL). - Taxon. 27(5-6): 481-484.

Authors' addresses: Marcin Nobis, Agnieszka Nobis, Elżbieta Jędrzejczak \& Ewelina Klichowska, Departament of Plant Taxonomy, Phytogeography and Herbarium, Institute of Botany, Jagiellonian University, Kopernika 27, 31-501 Kraków, Poland; Marcin Nobis, Laboratory of Biodiversity and Ecology, Institute of Biology, Tomsk State University, 36 Lenin Prospekt, Tomsk, 634050, Russia

Corresponding author: m.nobis@uj.edu.pl. 